\title{
ANALYSIS OF PROFITABILITY PERFORMANCE: THE COMPARISON OF BPR KOTA BARU AND BPR IN SOUTH KALIMANTAN PROVINCE DURING COVID-19 PANDEMIC PERIOD
}

\author{
Wangsit Supeno \\ Accounting Information System Program, Faculty of Engineering and Information, Bina Sarana Informatika \\ University, Jl. RS Fatmawati No. 24 Jakarta Selatan, 12450, Indonesia \\ E-mail: wangsit.wss@bsi.ac.id
}

\begin{abstract}
The impact of the Covid-19 pandemic is strongly felt for the Rural Banks (or BPR) industry operating in South Kalimantan province. This study is a case study of BPR Kota Baru operating in South Kalimantan Province. Based on the financial report published by Financial Services Authority (or OJK), the BPR Kota Baru is one of the banks that has the best Return On Asset (ROA) performance, because the ROA ratio continues to grow during the Covid-19 pandemic. The purpose of this study is to find out the extent of the performance of Return On Asset or ROA of BPR Kota Baru compared to the ROA Performance of some $B P R$ in South Kalimantan Province before and during the Covid-19 pandemic has a positive ROA. Analysis of research data is sourced from the financial statements of conventional BPR publications accessed on the website of OJK. This study conducts comparative research methods and finds that during the Covid-19 pandemic the ROA of BPR Kota Baru for September 2020 is $6.74 \%$ while the average ROA ratio of other BPR is $4.80 \%$. On asset management and operational cost efficiency to operating income (BOPO), the management of BPR Kota Baru manage to improve profitability capability in the midst of the Covid-19 pandemic in the position of financial statements published in September 2020.
\end{abstract}

Keywords: performance; ROA; profitability; $B O P O$

JEL Classification: G21, G24, G28

Article info:

Received 2 April 2021

Revised 3 April 2021

Accepted 3 April 2021

Available online 3 April 2021

\section{INTRODUCTION}

One of the success of the operational performance of Rural Banks (BPR) can be analyzed based on the ability to obtain profitability through financial reports that have been published by the BPR every quarter to the Financial Services Authority (OJK), and the public can access the published financial reports of the BPR through the OJK website. BPR is a bank financial institution whose operations are based on Banking Law No. 10 of 1998, is limited to collecting funds from the public in the form of savings and time deposits and activities to channel rural funds in the form of providing credit to the public, both in the form of working capital, consumptive and small investment loans.

The profitability ratio shows the company's management's ability to create profits. Profits at the maximum level are the main objective in bank operations. Many indicators can be used to measure profitability, including Return On Assets (ROA). ROA is a ratio that can be used to determine and measure the ability of a company or bank to earn earnings by utilizing all its assets. If the ROA of a bank is getting bigger, the greater the profit that can be obtained by the bank and thus the better the bank is in terms of using its assets (Afriyeni, 
2017). Ikhwal (2016) finds that Return On Asset (ROA) and Return On Equity (ROE) are indicators for assessing the company's financial performance where the higher the ROA and ROE values, the higher the rate of return received. ROA is one of the profitability ratios used to measure the effectiveness of a company in generating profits by utilizing its total assets. According to Căpraru and Ihnatov (2014), the determining factors for bank profitability are internal factors (bank size, liquidity risk, credit risk, business mix financial structure) and bank external (economic growth and inflation). This indicates that management efficiency or Operational Expenses on Operational Income (or BOPO) and Capital Adequacy Ratio (CAR) affect bank profitability for all proxies used (Afriyeni and Fernos, 2018).

Chatarine and Lestari (2014) find that high BOPO indicates that the operational performance of the bank to generate income is not efficient so that it has an impact on reducing profitability. This is because the profits earned are used to cover losses arising from large bank operational costs. In BPR operations, assets or assets consist of productive assets and non-earning assets. Earning assets are assets that provide income regularly every month, in this case in the form of loans. The level of profitability of the BPR is determined by the operating income earned in each period. The main source of income for conventional BPRs is interest income from loans. Credit interest income will increase, if the amount of credit extended by BPRs continues to increase, followed by the smooth operation of customers in paying installments, both principal and interest (Supeno and Hendarsih, 2020). Mulyadi and Din (2018) find that capital adequacy ratios, non-performing loans, net interest margins, operating expenses to operating income, and loan to deposit ratios collectively or simultaneously affect return on assets by $92.7 \%$, while the remaining $7.3 \%$ due to other causes.

This sudy shows that in order to increase ROA, BPRs must be able to manage assets owned, among others, from capital and public funds, including cost efficiency and quality of credit provided by enlarging loans of current quality, which determines the increase in income and the ability of BPRs to earn profits. before tax. The impact of the Covid-19 pandemic has been felt by all economic players, both individuals and companies, including the BPR industry in Indonesia, where the largest customers are the middle and lower class, and the majority touch the Micro, Small and Medium Enterprises (MSMEs) sector. The role of management in managing BPRs affected by the Covid-19 pandemic in April to September 2020 will determine the resilience of BPRs in overcoming problems that arise related to weakening economic conditions, and strive for BPRs to continue to have the opportunity to continue to grow both their assets and profitability. will determine the continuity of the BPR's business in the future. Ningsih and Mahfudz (2020) in a comparative study on Bank Syariah Mandiri, Bank Mega Syariah, Bank Syariah Bukopin, Bank Victoria Syariah, and Bank Jabar Banten Syariah proved that there was a fluctuation in banking intermediation functions such as financing and Third Party Funds (TPF) during the Pandemic Covid-19.

Assessment of profitability performance with the ROA indicator from BPRs can be done by analyzing the published financial reports of conventional BPRs through the official website of the OJK (https://www.ojk.go.id) where published financial reports must be submitted by BPRs every March, June, September and December online to OJK. Facts from the Indonesian Banking Statistics in September 2020 show that the condition of the profitability performance (ROA indicator) of BPRs nationally experienced significant turmoil during the Covid-19 pandemic. This indicates that the national BPR profitability in September 2020 has decreased compared to the previous year where ROA fell to $1.95 \%$ from $2.29 \%$ in the previous year. The decline was due to current year profit contracting $-11.95 \%$ (yoy) from $1.05 \%$ a year earlier. In addition, the efficiency of BPRs has also decreased due to the increase in the BOPO ratio to $84.41 \%$ (Financial Services Authority, 2020). This study aims to determine the profitability performance (with the ROA indicator) with a comparative 
study before and during the Covid-19 pandemic at BPR Kota Baru with several BPRs in South Kalimantan. Indonesian Banking Statistics Data (SPI) shows that the number of BPRs in South Kalimantan Province is 14 BPRs of which 4 BPRs including BPR Kota Baru had healthy ROA performance before the Covid-19 pandemic in September 2019, and during the Covid-19 Pandemic in September 2020.

\section{LITERATURE REVIEW}

\subsection{The Covid-19 Pandemic}

Covid-19 is an infectious disease caused by acute respiratory syndrome coronavirus 2 (severe acute respiratory syndrome coronavirus 2 or SARS-CoV-2). Covid-19 has since been found to have spread widely, resulting in a global pandemic that has continued until now (Amri, 2020). The Covid-19 virus has had a significant impact on world economic development so that the Covid-19 pandemic is a challenge for the business world, including the banking financial services industry (Ningsih and Mahfudz, 2020).

\subsection{Financial performance}

The bank's financial performance is one of the banking performances which is a description of the achievements achieved by the bank in its operations, both regarding the aspects of finance, marketing, collection and distribution of funds, technology and human resources (Alinda and Kusuma, 2018). Internally, company management uses financial analysis in carrying out internal control and presents the things needed by capital providers to see the company's financial condition and performance (Van Horne and Wachowicz, 2009: 128). The company's financial performance is useful for assessing the success of the company in running its business through financial management (Dewi and Suryantini, 2018).

Publication financial reports. Financial reports are the main or final result of an accounting process that becomes information for users in making decisions as well as describing the indicators of a company's success in achieving its goals (Weygandt et al., 2018: 23-3; Rahmayeli and Marlius, 2018). Financial Services Authority Regulation (POJK) Number 39/SEOJK.03/2017 requires the publication of financial reports at the end of March, June, September and December with predetermined standards. Financial Services Regulation (POJK) Number 48/POJK.03/2017 states that a Published Financial Report is a BPR financial report prepared based on financial accounting standards applicable to BPR and BPR accounting guidelines and published quarterly in accordance with the Financial Services Authority Regulation (Supeno, 2019).

Purpose of published financial reports. Financial reports can be applied with the aim of providing information relating to the position, performance and changes in the financial position of a company which is useful for making corporate economic decisions (Rabuisa et al., 2018). Published Financial Reports are prepared to provide information on financial reports, other information, the composition of the Board of Directors and the Board of Commissioners, as well as the composition of shareholders including controlling shareholders on a quarterly basis to various parties with an interest in the development of the BPR business (Financial Services Authority, 2017).

\subsection{Profitability}

Profitability is a ratio that shows the ability to achieve planned profit. For shareholders or company owners, this ratio shows the level of return on investment (Simanjuntak, 2019). Profitability is a measurement tool used by management to determine company performance, and the level of profitability describes the company's profit position, which can influence investor policies regarding investment (Tampubolon and Prima, 2020).

Return on Asset (ROA). ROA is a form of profitability ratio to measure a company's 
ability to generate profits by using total assets and after capital costs or costs used to fund assets (Financial Services Authority, 2020; Brigham and Ehrhardt, 2017:115). ROA is the ratio of net tax returns which also means a measure to assess how much the rate of return of assets owned by the company (Ikhwal, 2016). ROA is a tool to determine the level of effectiveness of a company in generating profits by utilizing its assets so that the greater the ROA of the bank, the higher the level of profit the bank gets and the better the bank's position (Afriyeni, 2017). Profit is often used as the main source for measuring company performance. Profit is an increase in economic benefits during an accounting period in the form of income, changes in assets, or a decrease in liabilities that causes an increase in equity that does not come from the contribution of additional capital (Nursita, 2021). The main business undertaken by BPRs is to provide credit, reflected in nearly $70 \%-80 \%$ of bank assets in the form of loans. Likewise, bank income mainly comes from lending activities in the form of interest income and credit provisions (Supeno, 2017).

Operating Expenses to Operating Income (or BOPO). According to Mulyadi and Din (2018), BOPO is the ratio between operating costs and operating income. Operational costs are costs incurred by the bank in carrying out its main business activities, such as interest costs, marketing costs, labor costs and other operating costs. Operating income is the main income of the bank, namely income obtained from placement of funds in the form of credit and other operating income. The Central Bank of Indonesia assesses that the condition of bank profitability in Indonesia is based on two indicators, namely ROA or BOPO (Mawaddah, 2015). Operational efficiency in banking can show the ability of a bank to manage its business. According to The Central Bank of Indonesia, operational efficiency is measured by comparing total operating costs with total operating income or what is known as BOPO. The ratio of operating costs is the ratio between operating costs and operating income (Marginingsih, 2018).

\section{RESEARCH METHOD}

\subsection{Data types and sources}

This study uses a comparative method. According to Sugiyono in Dewi and Suryantini (2018), comparative study is research that compares the state of one or more variables in two or more different samples, or two different times. This comparative study was conducted by comparing profitability financial ratios which include ROA and the related ratio, namely BOPO. This research is a case study of BPR Kota Baru in South Kalimantan Province, by conducting a comparative analysis of ROA and BOPO performance at BPR Kota Baru with several BPRs also operating in one province. This research is based on secondary data in the form of financial reports published by BPRs through the official website of the OJK, especially BPR financial reports for the position of September 2019 (before the Covid-19 pandemic occurred) until September 2020 (when the Covid-19 pandemic was still ongoing).

\subsection{Samples and sampling techniques}

The sample criteria of this study are all BPR located and operating in South Kalimantan Province, BPRs that routinely submitted published financial reports to the OJK publicly, and BPRs that had healthy criteria for ROA in the position of September 2019 (before the Covid-19 pandemic) until September. 2020 (when the Covid-19 pandemic is still happening). Based on these criteria, there are 4 (four) BPRs that have a healthy ROA out of 14 existing BPRs, namely BPR Kota Baru, BPR Multidhana Bersama, BPR Mitratama Arthabuana, and BPR Sanggam Cipta Sejahtera with a focus on BPR Kota Baru because it has ROA. the largest of all BPRs operating in the province of South Kalimantan. In addition, the BOPO condition which is closely related to the ability of BPR to earn profit before tax 
will be analyzed in this study. According to Kusmayadi (2017), based on Circular Letter Number 13/24/DPNP dated October 25, 2011, the Central Bank of Indonesia determined that an ROA of 1.5 percent was categorized as healthy. ROA is obtained using the formula:

$$
\text { ROA }=\frac{\text { Earning before tax }}{\text { Average of Total Asset }} \times 100 \%
$$

According to Yanti and Afriyeni (2007), the Decree of the Board of Directors of Bank Indonesia Number 30/12/KEP/DIR dated April 30, 1997 determines that a healthy BPR has a maximum BOPO of $93.52 \%$ because if the BOPO ratio exceeds the predetermined number it is even close to $100 \%$ then the bank can be said to be inefficient in carrying out its operational activities. The BOPO formula is:

$$
\text { BOPO }=\frac{\text { Total Operation Expense }}{\text { Total Operation Revenue }} \times 100 \%
$$

\section{RESULTS AND DISCUSSIONS}

\subsection{Results}

BPR Kota Baru is one of the BPRs with the best and healthiest ROA performance in South Kalimantan Province as of September 2020. In the midst of the Covid-19 Pandemic, the BPR Kota Baru is still able to improve their business performance with an ROA ratio above the average ROA of BPRs in the South Kalimantan Province. Table 1 shows that BPR Kota Baru located in Kota Baru Regency in South Kalimantan Province had an ROA of 6.7\% in the position of September 2020. This indicates that the profitability performance or ROA at BPR Kota Baru is the highest and is in the healthy category compared to 3 (three) other BPRs in the same province. In September 2019, the highest position for profitability or ROA was BPR Sanggam Cipta Sejahtera, located in Balangan Regency, namely 5.8\% while BPR Kota Baru was 5.6\%. When compared on average with all BPRs with an ROA ratio of $5.1 \%$ in September 2019 and 4.8\% in September 2020, Kota Baru BPRs are in good health before and after the Covid-19 pandemic. Kota Baru BPRs experienced an ROA growth of 20.6\% while other BPRs experienced a decrease in ROA during the Covid-19 pandemic. BPR Multidhana Bersama experienced a significant decrease in ROA, reaching 27.5\%, followed by BPR Mitratama Arthabuana by $14.5 \%$ and BPR Sanggam Cipta Sejahtera, which decreased by $6.2 \%$ but overall it was still in the healthy category.

Table 1. The comparison of ROA performance (September 2019 - September 2020)

\begin{tabular}{clccc}
\hline No. & \multicolumn{1}{c}{ Bank's name } & $\begin{array}{c}\text { ROA } \\
\text { Sept 2020 } \\
\text { (Thousand IDR) }\end{array}$ & $\begin{array}{c}\text { ROA } \\
\text { Sept 2019 } \\
\text { (Thousand IDR) }\end{array}$ & $\begin{array}{c}\text { Growth of } \\
\text { ROA } \\
(\mathbf{\%})\end{array}$ \\
\hline 1 & BPR Kota Baru & $6,7 \%$ & $5,6 \%$ & $20,6 \%$ \\
2 & BPR Multidhana Bersama & $3,4 \%$ & $4,7 \%$ & $-27,5 \%$ \\
3 & BPR Mitratama Arthabuana & $3,8 \%$ & $4,4 \%$ & $-14,5 \%$ \\
4 & BPR Sanggam Cipta Sejahtera & $5,3 \%$ & $5,8 \%$ & $-8,6 \%$ \\
& Rata-Rata & $4,8 \%$ & $5,1 \%$ & $-6,2 \%$ \\
\hline
\end{tabular}

Source: Publication Report of Conventional BPR on September 2019-2020

Table 2 shows that BPR Kota Baru during the period September 2019 to September 2020 are classified as efficient because able to reduce the BOPO by the greatest amount of $6.1 \%$, at a time when the average BOPO of several BPRs increased by $2.8 \%$. BPR Multidhana Bersama is a BPR that has increased the BOPO ratio of $8.7 \%$, BPR Mitratama Arthabuana has increased by 5.6\% and BPR Sanggam Cipta Sejahtera has increased by 5\%. 
In September 2020, the average BOPO of BPR performance was $70.3 \%$, while the BOPO BPR Kota Baru showed a figure of $73.7 \%$, so there was an increase in BOPO of around $3.4 \%$. The BPR that has the lowest BOPO is BPR Mitrathama Arthabuana, which is $66.5 \%$ in September 2020, but the condition is inefficiency of 5.6\% compared to 2019. The results of this study support Putri et al. (2018) which shows that BOPO has a significant negative effect on profitability which proves that if the operational costs of BPR in Denpasar City increase, the profitability obtained will decrease.

Table 2. The comparison of BOPO performance (September 2019 - September 2020)

\begin{tabular}{clccc}
\hline No. & \multicolumn{1}{c}{ Bank's name } & $\begin{array}{c}\text { BOPO } \\
\text { Sept 2020 } \\
\text { (Thousand IDR) }\end{array}$ & $\begin{array}{c}\text { BOPO } \\
\text { Sept 2019 } \\
\text { (Thousand IDR) }\end{array}$ & $\begin{array}{c}\text { Growth of } \\
\text { BOPO } \\
\text { (\%) }\end{array}$ \\
\hline 1 & BPR Kota Baru & $73,7 \%$ & $78,5 \%$ & $-6,1 \%$ \\
2 & BPR Multidhana Bersama & $70,7 \%$ & $65,0 \%$ & $8,7 \%$ \\
3 & BPR Mitratama Arthabuana & $66,5 \%$ & $62,9 \%$ & $5,6 \%$ \\
4 & BPR Sanggam Cipta Sejahtera & $70,5 \%$ & $67,1 \%$ & $5,0 \%$ \\
& Rata-Rata & $70,3 \%$ & $68,4 \%$ & $2,8 \%$ \\
\hline
\end{tabular}

Source: Publication Report of Conventional BPR on September 2019-2020

\subsection{Discussions}

The results indicated that BPR Kota Baru had the greatest growth in profitability or ROA compared to the other 3 (three) BPRs even though they were in a state of the Covid-19 pandemic. During the Covid-19 pandemic, the profitability performance or ROA of BPR Kota Baru in September 2020 increased by $20.6 \%$ to $6.7 \%$, making it classified as healthy, while the average ROA for BPRs was $4.8 \%$. These results prove that BPR Kota Baru has a better ability to earn profits with its total assets, compared to the other three BPRs that experienced a decrease in profitability or ROA. This study found 2 (two) important factors that became the success of Kota Baru BPR management in increasing ROA during the Covid19 pandemic crisis.

The first factor is that the management of BPR Kota Baru is able to collect funds from the public at interest rates in accordance with the provisions of the Deposit Insurance Corporation (or LPS). Management is able to use assets sourced from public funds for the distribution of productive assets in the form of loans to communities that continue to experience growth, and manage healthy credit so that the Non-Performing Loan ratio is below 5\%. Loans disbursed by BPR Kota Baru consist of a productive credit proportion of $33 \%, 60 \%$ consumptive credit, and 7\% MSME financing. During the Covid-19 pandemic the MSME sector experienced an unfavorable impact so that the management of BPR Kota Baru applied the principle of prudence in the process of providing credit even though the location of BPR Kota Baru is classified as strategic considering it is in the Limbur Raya market.

The second factor is the management ability of BPR Kota Baru in carrying out BOPO efficiency where BPR Kota Baru is able to reduce BOPO from $78.5 \%$ in the position of September 2019 to $73.7 \%$ in September 2020, or decrease by 6.1\%. During the Covid-19 pandemic, the management of BPR Kota Baru is able to make efficiency and this is the right strategy to maintain the health of the financial performance of BPR Kota Baru in the next period when the pandemic still hampered economic growth, especially MSME players who became BPR customers. In the midst of the Covid 19 pandemic, the management of BPR Kota Baru is able to maintain credit growth and credit health as measured by the NonPerforming Loan ratio. In addition, prudent management measures in granting credit, and also in terms of operational costs related to administrative and general costs, will greatly support the creation of operational efficiency for BPR Kota Baru. During the Covid-19 pandemic from April 2020 to September 2020, the management of BPR Kota Baru is able to reduce administrative and general costs, thus making a positive contribution in increasing 
profitability with the ROA indicator. The efficiency of BOPO from BPR Kota Baru before the Covid-19 pandemic was $78.5 \%$ and was below the $93.52 \%$ limit, coupled with the efforts made by management in managing operating income from loans that have been channeled to the public optimally with the principle of prudence, and by carrying out operational cost efficiency, make BPR Kota Baru able to occupy the top position in profitability or ROA performance compared to BPR Multidhana Bersama, BPR Mitratama Arthabuana and BPR Sanggam Cipta Sejahtera in the position of September 2020.

\section{CONCLUSIONS AND SUGGESTIONS}

\subsection{Conclusion}

During the Covid-19 pandemic, BPR Kota Baru succeeded in increasing profitability or ROA as of September 2020 by $6.7 \%$ above the average of $4.8 \%$. The condition of ROA for the BPR Kota Baru is considered to be the best and healthy compared to the other three healthy BPRs in South Kalimantan Province. The Covid-19 pandemic had a negative impact on the ability of BPRs in South Kalimantan Province to obtain optimal ROA, this was indicated by the average BPR other than Kota Baru BPR experiencing a decrease in ROA. The ability of the management of the BPR Kota Baru in managing assets strategies, and carrying out operational cost efficiency and increasing operating income, was able to make BPRs survive during the Covid-19 pandemic, even still be able to achieve the best and healthy ROA. This is indicated by a healthy BOPO with a lower ratio than before the Covid19 pandemic, which was $78.5 \%$ to $73.7 \%$.

\subsection{Suggestion}

This study suggests that the management of BPR Kota Baru increase total assets, especially productive assets, through careful lending and efforts to settle non-performing loans, in order to obtain funds that can be channeled back to generate income from lending. In addition, the management of BPR Kota Baru should use cheap sources of funds from the public, while maintaining cost efficiency, including reducing the burden of credit risk in the form of write-offs of productive assets. Future research in the same field of study should add other variables such as the performance of credit disbursements and the ratio of nonperforming loans (NPL).

\section{REFERENCES}

Afriyeni. (2017). Profitabilitas Bank Perkreditan Rakyat di Kota Padang ditinjau dari rasio likuiditas. Jurnal Benefita, 22-32. http://ejournal.lldikti10.id/index.php/benefita/article/view/2104

Afriyeni, \& Fernos, J. (2018). Analisis faktor-faktor penentu kinerja profitabilitas Bank Perkreditan Rakyat (BPR) konvensional di Sumatera Barat. Jurnal Benefita, 3(3), 325-335. http://ejournal.lldikti10.id/index.php/benefita/article/view/3623

Alinda, P. D., \& Kusuma, H. (2018). Analisa kinerja keuangan Bank Perkreditan Rakyat di Wilayah Malang Raya. Jurnal Ilmu Ekonomi, 2(3), 419-427. https://ejournal.umm.ac.id/index.php/jie/article/view/7100

Amri, A. (2020). Dampak Covid-19 terhadap UMKM di Indonesia. Jurnal Brand, 2(1), 123130. https://ejournals.umma.ac.id/index.php/brand/article/view/605

Brigham, E. F., \& Ehrhardt, M. C. (2017). Financial management: Theory and practice, 15th Edition. United States: Cengage Learning. 
Căpraru, B., \& Ihnatov, I. (2014). Banks' Profitability in Selected Central and Eastern European Countries. Procedia Economics and Finance, 16, 587-591. https://doi.org/10.1016/S2212-5671(14)00844-2

Chatarine, A., \& Lestari, P. V. (2014). Pengaruh kualitas aktiva produktif, BOPO terhadap ROA dan CAR pada BPR Kabupaten Badung. E-Jurnal Manajemen, 3(3), 561-577. https://ojs.unud.ac.id/index.php/Manajemen/article/view/6901

Dewi, P. Y. K., \& Suryantini, N. P. S. (2018). Analisis perbandingan kinerja keuangan perusahaan sebelum dan sesudah akuisisi. E-Jurnal Manajemen, 7(5), 2323-2352. https://doi.org/10.24843/EJMUNUD.2018.v07.i05.p01

Ikhwal, N. (2016). Analisis ROA dan ROE terhadap profitabilitas bank di Bursa Efek Indonesia. Al-Masraf: Jurnal Lembaga Keuangan dan Perbankan, 1(2), 211-227. https://journal.febi.uinib.ac.id/index.php/almasraf/article/view/57

Kusmayadi, D. (2017). Penilaian kesehatan Bank Perkreditan Rakyat dengan faktor CAMEL. Jurnal Akuntansi, 12(1), 1-19. http://jurnal.unsil.ac.id/index.php/jak/article/view/299

Marginingsih, R. (2018). Faktor-faktor yang mempengaruhi profitabilitas bank umum syariah di Indonesia. Jurnal Ecodemica, 2(1), 74-85. https://ejournal.bsi.ac.id/ejurnal/index.php/ecodemica/article/view/2904

Mawaddah, N. (2015). Faktor-faktor yang mempengaruhi profitabilitas bank syariah. Etikonomi, 14(2), 241-256. https://doi.org/10.15408/etk.v14i2.2273

Mulyadi, D., \& Din, A. (2018). Analisis pengaruh rasio keuangan terhadap return on asset Bank Perkreditan Rakyat pada PT. BPR Polin Jaya. Jurnal Manajemen \& Bisnis Kreatif, 3(2), 14-43. https://doi.org/10.36805/manajemen.v3i2.250

Ningsih, M. R., \& Mahfudz, M. S. (2020). Dampak Pandemi Covid-19 terhadap manajemen industri perbankan syariah: Analisis komparatif. Point: Jurnal Ekonomi dan Manajemen, 2(1), 1-10. https://doi.org/10.46918/point.v2i1.576

Nursita, M. (2021). Pengaruh laba akuntansi, arus kas operasi, arus kas investasi, arus kas pendanaan, dan ukuran perusahaan terhadap return saham. Going Concern: Jurnal Riset Akuntansi, 16(1), 1-15. https://doi.org/10.32400/gc.16.1.32435.2021

Otoritas Jasa Keuangan. (2017). Surat Edaran Otoritas Jasa Keuangan Nomor 39/SEOJK.03/2017.

Otoritas Jasa Keuangan. (2020). Laporan Profil Industri Perbankan Triwulan III 2020.

Putri, N. K. A. P., Wiagustini, L. P., \& Abundanti, N. N. (2018). Pengaruh NPL, CAR dan BOPO terhadap profitabilitas pada BPR di Kota Denpasar. E-Jurnal Manajemen, 7(11), 6212-6238. https://doi.org/10.24843/EJMUNUD.2018.v07.i11.p15

Rabuisa, W. F., Runtu, T., \& Wokas, H. R. N. (2018). Analisis laporan keuangan dalam menilai kinerja keuangan perusahaan pada Bank Perkreditan Rakyat (BPR) Dana Raya Manado. Going Concern: Jurnal Riset Akuntansi, 13(02), 325-333. https://doi.org/10.32400/gc.13.02.19518.2018

Rahmayeli, D. S., \& Marlius, D. (2018). Analisis kinerja keuangan pada PT. Bank Perkreditan Rakyat (BPR) Batang Kapas Pesisir Selatan. https://doi.org/10.31227/osf.io/sz5db

Simanjuntak, J. (2019). Faktor mempengaruhi profitabilitas Bank Perkreditan Rakyat. Jurnal Kajian Ilmiah, 19(3), 213-221. https://jurnal.ubharajaya.ac.id/index.php/kajianilmiah/article/view/480

Supeno, W. (2017). Analisis kinerja penghimpunan dana dalam meningkatkan penyaluran kredit pada Bank Perkreditan Rakyat. Moneter, 4(2), 121-131. https://ejournal.bsi.ac.id/ejurnal/index.php/moneter/article/view/2336

Supeno, W. (2019). Analisis efisiensi BOPO terhadap laba bersih pada BPR. Jurnal Kajian Ilmiah, 19(2), 182-194. https://jurnal.ubharajaya.ac.id/index.php/kajianilmiah/article/view/460 
Supeno, W., \& Hendarsih, I. (2020). Kinerja kredit terhadap profitabilitas BPR pada masa pandemi Covid-19. Jurnal Akrab Juara, 5(4), 147-161. https://akrabjuara.com/index.php/akrabjuara/article/view/1290

Tampubolon, S., \& Prima, A. P. (2020). Pengaruh risiko keuangan terhadap profitabilitas pada Bank Perkreditan Rakyat di Kota Batam. Jurnal Akrab Juara, 5(3), 101-117. http://www.akrabjuara.com/index.php/akrabjuara/article/view/1168

Van Horne, J. C., \& Wachowicz, J. M. (2009). Fundamentals of financial management, $13^{\text {th }}$ Edition. England: Prentice-Hall, Inc

Weygandt, J. J., Kimmel, P. D., \& Kieso, D. E. (2018). Accounting Principles, $13^{\text {th }}$ Edition. United States: John Wiley \& Sons, Inc

Yanti, V. W., \& Afriyeni. (2007). Analisis rasio profitabilitas pada PT. Bank Perkreditan Rakyat (BPR) Cempaka Mitra Nagari Padang. https://doi.org/10.31219/osf.io/d3qrp 